\title{
An Equivalent Uniaxial Fatigue Stress Model for Analyzing Landing Gear Fuse Pins
}

\author{
K. Narayan, ${ }^{a}$ K. Behdinan, and P. Vanderpol ${ }^{\mathrm{b}}$ \\ ${ }^{a}$ Department of Aerospace Engineering, Ryerson University, Toronto, Canada \\ ${ }^{\mathrm{b}}$ Goodrich Aerospace Canada Ltd., Oakville, Canada
}

УДК 539.4

\section{Использование модели эквивалентного одноосного усталостного напряжения для расчета предохранительного шплинта шасси}

\author{
К. Нараян ${ }^{\mathrm{a}}$, К. Бехдинана, П. Вандерпол ${ }^{6}$ \\ а Отделение аэрокосмической механики, Райерсоновский университет, Торонто, \\ Канада \\ ๘ Гудрич Эйрспейс Канада Лтд., Оквилл, Канада \\ Рассмотрень условия двухосного напряженного состояния предохранительньх элементов \\ иасси - иплинтов в предохранительньд узлах. В этом случае имеет место сочетание каса- \\ тельных напряжений, уровень которьх соответспвует максилально допустилолу уровно \\ напряжений в конструкции, и сжимаючих напряжений, определяемьх из условий равно- \\ весия. Согласно стандартным методикал расчета на усталость такое сочетание напря- \\ жений заменяется эквивалентныл одноосным напряжением, исходя из условий чистого \\ сдвига по Мизесу. При этом расчетнье усталостные характеристики материала оказыва- \\ ются существенно вылие, чем экспериментальные, полученные при усталостных испьта- \\ ниях иплинтов. Предлагается модель эквивалентного одноосного усталостного напря- \\ жения, в которой учитывается разгрузочный эффект сжимаюиих напряжений. Модель \\ используется в ралках стандартного пакета програлм расчета деформационньх кривьх \\ усталости (Goodrich Aerospace's Fatigue Life V2) для оценки усталостной долговечности \\ предохранительного иплинта иасси под действием циклических нагрузок. Полученнье ре- \\ зультатьл сравниваются с определенньли с полочию модели чистого сдвига и расчетной \\ конечноэлементной программь. Использование предложенной модели обеспечивает оценку \\ усталостной долговечности менее консервативную, чем эквивалентная модель Мизеса, но \\ более завьиенную, чем двухмерньй конечноэлементный расчет.
}

Ключевые слова: шасси, двухосное напряженное состояние, усталость, двухмерный конечноэлементный расчет.

\section{Nomenclature}

$f(K)$ - extrema fitting function

$K \quad-$ fuse groove compressive to shear stress ratio

$K_{s h} \quad-$ ratio of average shear stress to maximum shear stress

$R_{L} \quad$ - fatigue cycle load ratio

$\gamma \quad-$ principal plane orientation with respect to current stress plane

$\sigma \quad-$ normal stress 


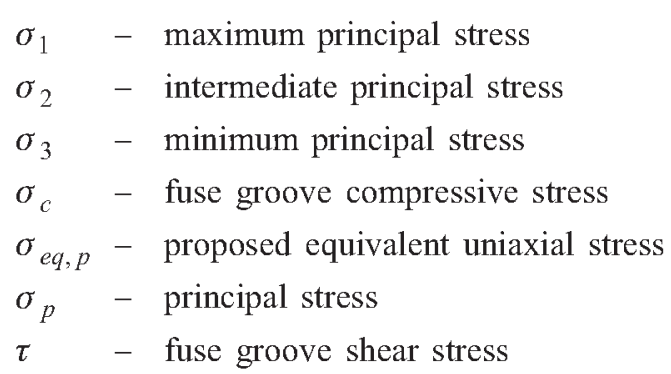

Introduction. This paper attempts to propose an easy-to-implement, industryminded, equivalent uniaxial fatigue stress model for the non-proportional, biaxial state of stress in the fuse groove of a landing gear fuse pin. There are only a few stress or strain based fatigue analysis techniques that are widely used in the aerospace industry to predict multiaxial fatigue damage on aircraft components. Most companies do not have the resources to carry out complex energy or critical-plane based calculations of multiaxial fatigue damage: the software necessary to do the calculations is involved and expensive to develop or buy. Many aerospace companies today, however, have strain-life fatigue analysis software that requires an equivalent uniaxial stress for the multiaxial stress state as input. The software uses the equivalent uniaxial stresses in traditional uniaxial strain-life theories to determine the fatigue damage. The most popular equivalent uniaxial stress for this purpose is the von Mises stress for the multiaxial stress state. Plasticity correction models are available to use linear stresses to predict low-cycle fatigue (LCF) damage.

The literature on multiaxial fatigue is abound with various advanced fatigue models for predicting multiaxial fatigue damage. However, each is limited in its usefulness to the practising aerospace engineer. Gonçalves et al. [1] have proposed a stress-based multiaxial fatigue criterion for hard metals. However, this criterion can only be used for fail-safe design of components, i.e., it only predicts whether the metal will experience fatigue failure or not. The criterion cannot be used to actually calculate the fatigue damage. Kim and Yamada [2] have proposed an equivalent stress-range based model for predicting fatigue lives of welds under combined normal and shear stress cycles, but this model only applies to proportional loading and hence is not applicable to landing gear fuse pins (it will be shown shortly that the loading is non-proportional in nature). Kyuba and Dong [3] have used the equilibrium-equivalent structural stress method (the outcome of a joint industrial project) for fatigue analysis of a rectangular hollow section joint. The biggest disadvantage of this method is that it requires nodal forces from a detailed finite-element analysis (FEA) as input and therefore is of limited utility for preliminary design of the fuse pin. Hong and Shaobo [4] have predicted biaxial stress fatigue life using the local strain method. However, the biaxial stress state arises solely due to the Poisson effect of plane strain, which is the only case considered. This is too limited to be applied to a fuse pin. Carpinteri and Spagnoli [5] have presented a multiaxial high cycle fatigue criterion for hard metals. Again, this criterion can only be used for fail-safe design of components: it only predicts whether fatigue failure will occur or not. Finally, Bäckström and Marquis [6] have reviewed critical plane approaches for predicting multiaxial fatigue of weldments. 
The methods can be extended to fuse pins, but critical plane approaches are complicated and impractical to be used by many companies, as already mentioned.

In light of all these facts, the equivalent uniaxial stress model proposed in this paper is simple enough to be implemented in most conventional strain-life fatigue analysis software that takes uniaxial fatigue stresses as input. The model captures the non-proportional biaxial state of stress in the fuse pin and overcomes the conservativeness of the von Mises equivalent stress for this stress state. This makes the model especially useful for relatively accurate preliminary design of landing gear fuse pins.

1. Limitations of the Pure Shear von Mises Equivalent Uniaxial Stress for Landing Gear Fuse Pin Fatigue Predictions. Landing gear fuse pins are shear pins that are designed to fail at a specific static shear load. One or more of these pins are used in critical load paths of a landing gear assembly to initiate a controlled failure sequence of the landing gear. Crashworthiness requirements for aircrafts state that during a crash sequence, the landing gear must fail so as to avoid inducing airframe ruptures that could be hazardous or catastrophic for the safety of the occupants. Since all loads exerted on a landing gear are ultimately reacted by the airframe, the goal is to ensure that the gear fails in a controlled manner before the loads being reacted by the airframe exceed the capabilities of the airframe gear-support points and rupture major structural elements like the wing-spar and the fuel tanks (which is catastrophic for the safety of passengers). Landing gear fuse pins are sized and located so that the gear fails in a precise sequence to sever all loads to the airframe gear-support points well before the ultimate loads of the airframe are reached. Once the gear fails, the airframe will no longer need to react any load.

The fuse pins are almost always used in a clevis configuration, resulting in two symmetric shear planes. Therefore landing gear fuse pins employ a dual grooved configuration. The grooves are circumferentially machined on the inner surface of a hollow pin and are usually either constant-radius, elliptical or parabolic. They are longitudinally positioned so that the sections with minimum area (i.e., sections through the troughs of the grooves) lie in the maximum shear-load planes. From a static perspective, fuse pin failure grooves are sized based on experimental/statistical design curves that give shear-failure load as a function of ultimate shear stress and groove dimensions for a particular material. The machined pin is then tested in a representative test rig until shear-failure occurs. The actual failure load is compared to the theoretical failure load to determine the shift in the design curves, and then a final groove size is determined. The static shift is almost always consistent among all test specimens, and is thereby easily incorporated in the final design.

The groove sections have relatively small areas since the prescribed failure load must be well below the ultimate design loads for the landing gear components. Only then will the pin fail before any of the landing gear components, thereby protecting the landing gear. Again, this is similar to choosing an electric fuse with a current rating well below the critical, damaging current.

These small areas, however, are not desired from a fatigue standpoint since the nominal stresses are quite high. By design, the maximum stress in the pin is 
the shear stress at the grooved section(s). Hence the fatigue analysis typically uses totally reversed states of pure shear to determine an equivalent uniaxial tensile stress (using a 'signed' von Mises stress, the sign being the same as that of the principal stress of maximum magnitude). This usually leads to unacceptable fatigue damage. But since the grooved section cannot be made larger (which results in a higher, potentially dangerous static failure load), a life limitation is placed on the pin based on the fatigue damage predicted using this simple model.

In reality, fatigue tests of fuse pins have shown significantly higher fatigue lives than those predicted by the afore-mentioned analysis. The reason for this is thought to be the compressive stress in the fuse groove that originates from bending and equilibrium compression. The equivalent uniaxial fatigue stress model proposed in this paper takes into account this compressive stress and predicts the fatigue life of a fuse pin more accurately, while ensuring that the analysis can be done using existing strain-life fatigue analysis software of the aerospace industry. The compressive stress is determined using a relatively simple contact FE model of a sample fuse pin. The model is then used with this compressive stress to obtain the input stresses for conventional discrete-section strain life fatigue analysis software. The results are then compared with an FE Fatigue run on the contact model using the same load spectrum.

2. Proposed Equivalent Uniaxial Fatigue Model. The fuse groove experiences a 2-D stress-state consisting of a shear stress and a compressive stress. The shear stress is most often the higher of the two. The compressive stress acts along the direction of the clevis and improves the fatigue life of the fuse pin at the fuse groove. The fatigue is therefore biaxial in nature and suitable theories have to be used to determine the biaxial fatigue damage.

The 2-D biaxial stress-state for one complete $R_{L}=-1$ cycle is shown in Fig. 1 (where stress states 1,3 , and 5 are unloaded states that form part of the complete cycle). The $R_{L}$ value is the load ratio, which is the ratio of maximum compressive clevis load in a cycle and the maximum tensile clevis load in the same cycle. A value of -1 simply means that the tensile and compressive loads are equal. This is not the case always, but is chosen for convenience to develop the theory.

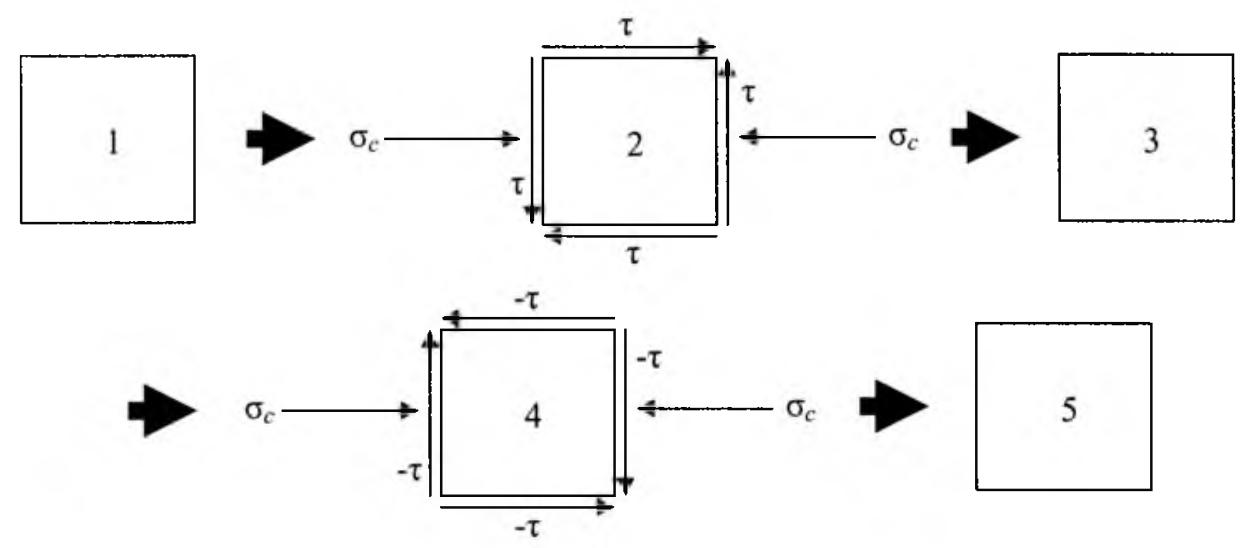

Fig. 1. 2-D stress states for one complete $R_{L}=-1$ load cycle in a fuse groove. 
The problem with the above stress state is that the loading is non-proportional. The axial stress is compressive irrespective of whether the shear stress is positive or negative. This complicates the biaxial fatigue analysis. However, the nonproportional loading in Fig. 1 can be converted into an approximate proportional one by using stress transformations. The Mohr's circle for stress-state 2 in Fig. 1 is shown in Fig. 2.

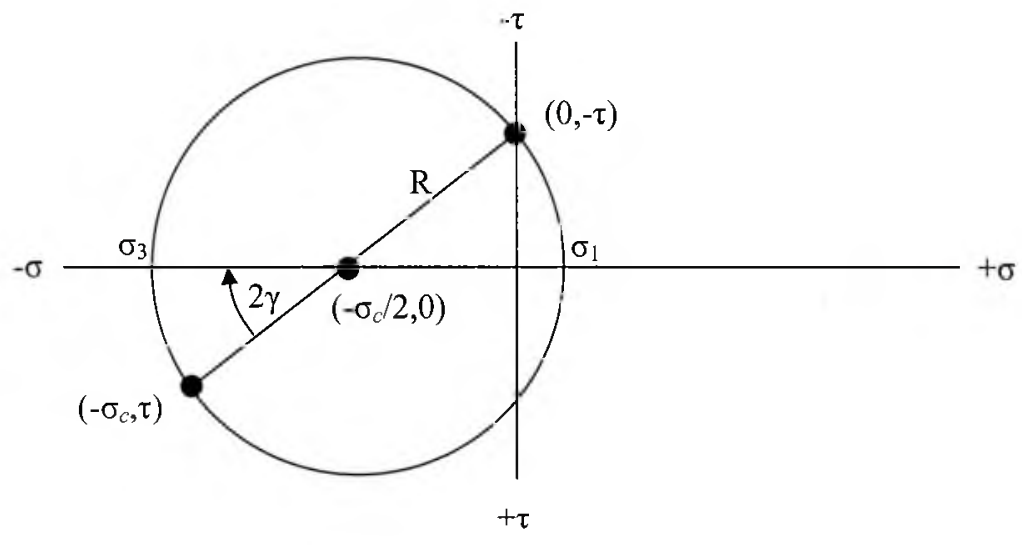

Fig. 2. Mohr's circle for stress state 2 in Fig. 1.

From Fig. 2, the principal stresses can be calculated as follows:

$$
\sigma_{1}=-\frac{\sigma_{c}}{2}+R=-\frac{\sigma_{c}}{2}+\sqrt{\left(\frac{\sigma_{c}}{2}\right)^{2}+\tau^{2}},
$$

$\sigma_{2}=0(2-\mathrm{D}$ stress state $)$

$$
\sigma_{3}=-\frac{\sigma_{c}}{2}-R=-\frac{\sigma_{c}}{2}-\sqrt{\left(\frac{\sigma_{c}}{2}\right)^{2}+\tau^{2}} .
$$

For a given fuse pin geometry, the ratio of $\sigma_{c}$ to $\tau$ is approximately constant in the elastic regime and will be denoted by $K$ :

$$
K=\frac{\sigma_{c}}{\tau} \Rightarrow \sigma_{c}=K \tau
$$

The value of $K$ can be found accurately by performing a finite element analysis of the fuse pin.

Using the value of $\sigma_{c}$ given by Eq. (3) in Eqs. (1) and (2), the principal stresses are finally:

$$
\sigma_{1}=\frac{\tau}{2}\left[-K+\sqrt{K^{2}+4}\right]
$$

and 


$$
\sigma_{3}=\frac{\tau}{2}\left[-K-\sqrt{K^{2}+4}\right]
$$

$\sigma_{2}$ will not be considered since it is always zero. From Eqs. (4) and (5), $\sigma_{3}$ is clearly negative while $\sigma_{1}$ is positive. Also, $\sigma_{3}$ is greater than $\sigma_{1}$ in magnitude. The closest principal stress plane is oriented at an angle $\gamma$, which can be easily determined as follows:

$$
\gamma=\frac{1}{2} \tan ^{-1} \frac{\tau}{\sigma_{c} / 2}=\frac{1}{2} \tan ^{-1} \frac{2 \tau}{\sigma_{c}}=\frac{1}{2} \tan ^{-1} \frac{2 \tau}{K \tau} \Rightarrow \gamma=\frac{1}{2} \tan ^{-1} \frac{2}{K}
$$

From Eq. (6), it is seen that $\gamma$ is a constant for a given value of $K$, i.e., for a given fuse pin geometry. The direction of rotation by $\gamma$ is clockwise, as indicated in Fig. 2.

The Mohr's circle for stress state 4 in Fig. 1 is shown in Fig. 3.

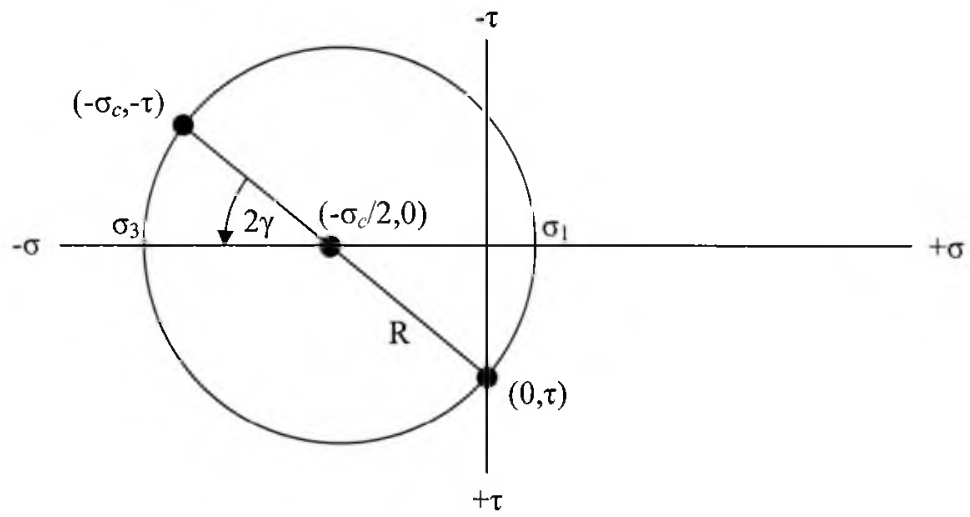

Fig. 3. Mohr's circle for stress state 4 in Fig. 1.

It can be verified that $\sigma_{1}, \sigma_{3}$, and $\gamma$ for this Mohr's circle are still given by Eqs. (4), (5), and (6). The only difference is that the direction of rotation of $\gamma$ is now counterclockwise instead of clockwise.

From the discussion above, stress states 2 and 4 in Fig. 1 can be drawn as shown in Fig. 4.

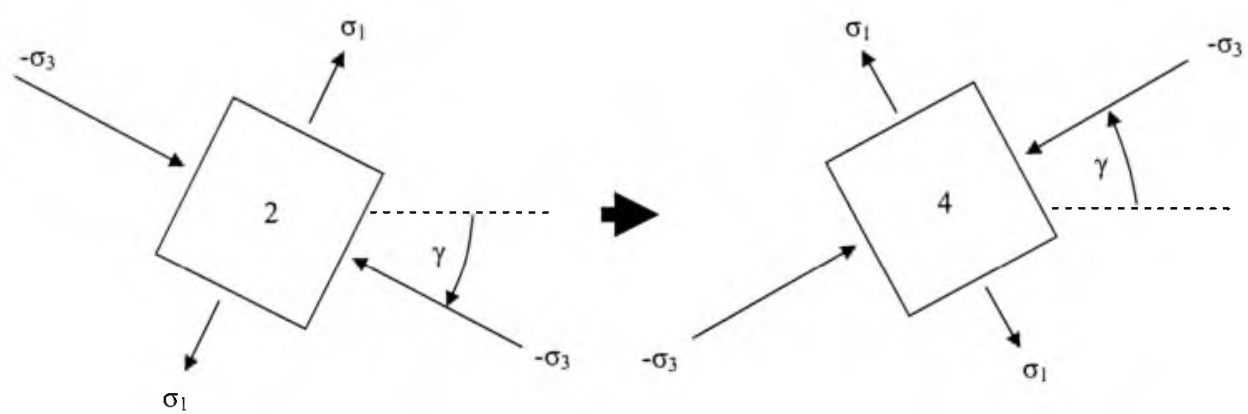

Fig. 4. 2-D stress transformations for stress states 2 and 4 of Fig. 1. 
The value of $\sigma_{3}$ is written as negative because it is shown in the compressive sense in Fig. 4. For values of $K$ from 0 to 1, $\gamma$ lies between 30 and $45^{\circ}$ [from Eq. (6)]. Therefore, it is reasonable and conservative to assume that $\gamma$ equals exactly $45^{\circ}$ for all these values of $K$. The assumption is conservative since the fully reversed state of stress is then placed along the same direction at all times. Hence $\gamma$ can be removed from the stress states 2 and 4, and loading scheme changes to Fig. 5.

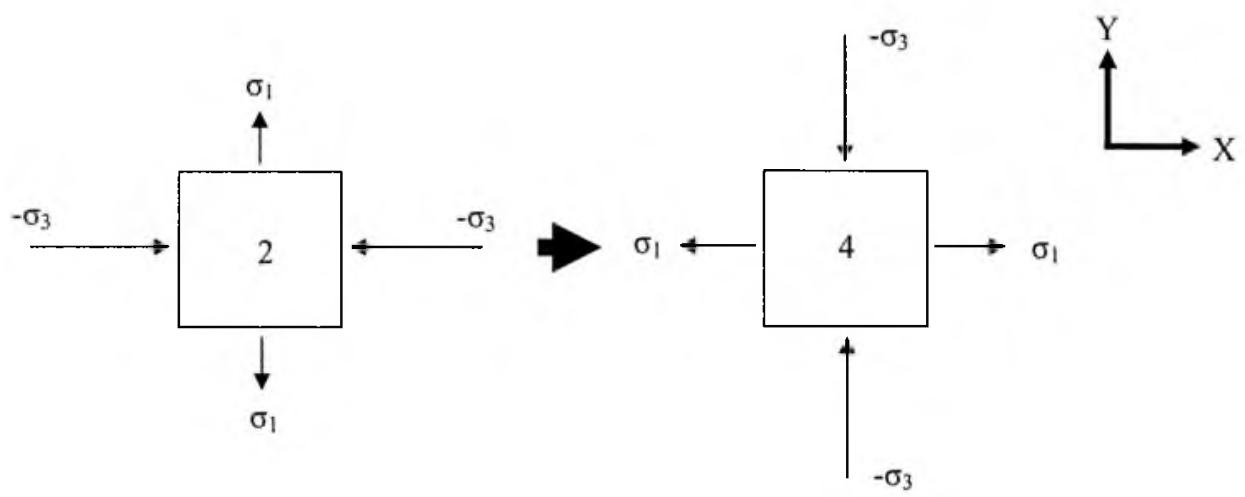

Fig. 5. Conservative approximation to stress states 2 and 4 in Fig. 4.

The real value of the transformations is realized by comparing Fig. 5 with Fig. 1. As mentioned before, the problem with the stress-cycle of Fig. 1 is that it is non-proportional. However, it has been transformed into the stress-cycle of Fig. 5, which is proportional: $\sigma_{x}$ and $\sigma_{y}$ are always opposite in sign to each other. Now the stress-cycle can be analyzed with relatively simple biaxial theories.

From Fig. 5, the stress along each axis cycles between $\sigma_{1}$ and $\sigma_{3}$. Hence, these stresses themselves can be used as the equivalent stresses, after suitably factoring them to capture the stress increase during the von Mises calculation.

From Eqs. (4) and (5), the principal stresses are:

$$
\sigma_{1}=\frac{\tau}{2}\left[-K+\sqrt{K^{2}+4}\right]
$$

and

$$
\sigma_{3}=\frac{\tau}{2}\left[-K-\sqrt{K^{2}+4}\right]
$$

The proposed equivalent uniaxial stress, $\sigma_{e q \cdot p}$, is

$$
\sigma_{e q, p}=\sqrt{3} \sigma_{p}
$$

where $\sigma_{p}$ is the principal stress along either the $x$ - or the $y$-axis for particular load. There are two alternatives that must be tested in this case, depending on the axis selected. The first alternative is to select the $x$-axis. Hence for a positive shear load: 


$$
\sigma_{e q 1, p 1}=\frac{\sqrt{3} \tau}{2}\left[-K-\sqrt{K^{2}+4}\right]
$$

and for a negative shear load

$$
\sigma_{e q 1, p 2}=\frac{\sqrt{3} \tau}{2}\left[-K+\sqrt{K^{2}+4}\right]
$$

The other alternative is to select the $y$-axis. Hence for a positive shear load

$$
\sigma_{e q 2, p 1}=\frac{\sqrt{3} \tau}{2}\left[-K+\sqrt{K^{2}+4}\right]
$$

and for a negative shear load

$$
\sigma_{e q 2, p 2}=\frac{\sqrt{3} \tau}{2}\left[-K-\sqrt{K^{2}+4}\right]
$$

Both alternatives must be tested and the worst fatigue damage must be taken as the final damage value.

The reasoning for Eq. (7) is as follows: let the $x$-axis be chosen for the principal stresses. Hence Eqs. (8) and (9) must be used. For the special case of pure shear, $K=0$ from Eq. (3), and Eqs. (8) and (9) yield:

$$
\sigma_{e q 1, p 1}=-\sqrt{3} \tau \quad \text { and } \quad \sigma_{e q 1, p 2}=\sqrt{3} \tau
$$

These are the signed von Mises stresses which are appropriate for the case of pure shear. For the special case of pure uniaxial compression, $K \rightarrow \infty$ and Eqs. (8) and (9) yield:

$$
\sigma_{e q 1, p 1}=-\sqrt{3} K \tau=-\sqrt{3} \sigma_{c} \quad \text { and } \quad \sigma_{e q 1, p 2}=0 .
$$

This is conservative for pure uniaxial compression (or tension, for that matter) since the stress is increased by a factor of $\sqrt{3}$. The correct stresses for $K=0$ and $K \rightarrow \infty$ can be obtained by multiplying the principal stresses by a function $f(K)$ instead of $\sqrt{3}$, defined in such a way that it is $\sqrt{3}$ when $K$ is zero and is 1 when $K \rightarrow \infty$. Equation (7) then becomes:

$$
\sigma_{e q, p}=f(K) \sigma_{p} .
$$

Some of the possible forms of $f(K)$ that satisfy the required extreme values are given next:

$$
f(K)=\frac{\sqrt{3}+m K}{1+m K},
$$




$$
\begin{aligned}
& f(K)=\frac{\sqrt{3}+\sqrt{m K}}{1+\sqrt{m K}}, \\
& f(K)=\frac{\sqrt{3+m K}}{1+\sqrt{m K}}, \\
& f(K)=\sqrt{\frac{3+m K}{1+m K}}, \\
& f(K)=\frac{\sqrt{3}+\sqrt{m K}}{\sqrt{1+m K}},
\end{aligned}
$$

where $m$ is any rational number.

The values of these functions for values of $K$ from 0 to 2 , and $K \rightarrow \infty$, for 3 values of $m$, are given in Tables 1-3.

T a b 1 e 1

Values of Reduction Functions for Practical Values of $K(m=0.1)$

\begin{tabular}{|c|c|c|c|c|c|}
\hline$K$ & $\frac{\sqrt{3}+0.1 K}{1+0.1 K}$ & $\frac{\sqrt{3}+\sqrt{0.1 K}}{1+\sqrt{0.1 K}}$ & $\frac{\sqrt{3+0.1 K}}{1+\sqrt{0.1 K}}$ & $\sqrt{\frac{3+0.1 K}{1+0.1 K}}$ & $\frac{\sqrt{3}+\sqrt{0.1 K}}{\sqrt{1+0.1 K}}$ \\
\hline 0 & 1.732 & 1.732 & 1.732 & 1.732 & 1.732 \\
\hline 0.25 & 1.714 & 1.632 & 1.502 & 1.718 & 1.867 \\
\hline 0.50 & 1.697 & 1.598 & 1.427 & 1.704 & 1.909 \\
\hline 0.75 & 1.681 & 1.575 & 1.377 & 1.691 & 1.935 \\
\hline 1.00 & 1.666 & 1.556 & 1.338 & 1.679 & 1.953 \\
\hline 1.25 & 1.651 & 1.541 & 1.306 & 1.667 & 1.966 \\
\hline 1.50 & 1.637 & 1.528 & 1.279 & 1.655 & 1.976 \\
\hline 1.75 & 1.623 & 1.516 & 1.256 & 1.644 & 1.984 \\
\hline 2.00 & 1.610 & 1.506 & 1.236 & 1.633 & 1.989 \\
\hline$\rightarrow \infty$ & 1.000 & 1.000 & 1.000 & 1.000 & 1.000 \\
\hline
\end{tabular}

$\mathrm{T}$ a b 1 e 2

Values of Reduction Functions for Practical Values of $K(m=1)$

\begin{tabular}{|c|c|c|c|c|c|}
\hline$K$ & $\frac{\sqrt{3}+K}{1+K}$ & $\frac{\sqrt{3}+\sqrt{K}}{1+\sqrt{K}}$ & $\frac{\sqrt{3+K}}{1+\sqrt{K}}$ & $\sqrt{\frac{3+K}{1+K}}$ & $\frac{\sqrt{3}+\sqrt{K}}{\sqrt{1+K}}$ \\
\hline 1 & 2 & 3 & 4 & 5 & 6 \\
\hline 0 & 1.732 & 1.732 & 1.732 & 1.732 & 1.732 \\
\hline 0.25 & 1.586 & 1.488 & 1.202 & 1.612 & 1.996 \\
\hline 0.50 & 1.488 & 1.429 & 1.096 & 1.528 & 1.992 \\
\hline 0.75 & 1.418 & 1.392 & 1.038 & 1.464 & 1.964 \\
\hline 1.00 & 1.366 & 1.366 & 1.000 & 1.414 & 1.932 \\
\hline
\end{tabular}


continuation Table 2

\begin{tabular}{|c|c|c|c|c|c|}
\hline 1 & 2 & 3 & 4 & 5 & 6 \\
\hline 1.25 & 1.325 & 1.346 & 0.973 & 1.374 & 1.900 \\
\hline 1.50 & 1.293 & 1.329 & 0.954 & 1.342 & 1.870 \\
\hline 1.75 & 1.266 & 1.315 & 0.938 & 1.314 & 1.842 \\
\hline 2.00 & 1.244 & 1.303 & 0.926 & 1.291 & 1.816 \\
\hline$\rightarrow \infty$ & 1.000 & 1.000 & 1.000 & 1.000 & 1.000 \\
\hline
\end{tabular}

$\mathrm{T}$ a b 1 e 3

Values of Reduction Functions for Practical Values of $K(m=10)$

\begin{tabular}{|c|c|c|c|c|c|}
\hline$K$ & $\frac{\sqrt{3}+10 K}{1+10 K}$ & $\frac{\sqrt{3}+\sqrt{10 K}}{1+\sqrt{10 K}}$ & $\frac{\sqrt{3+10 K}}{1+\sqrt{10 K}}$ & $\sqrt{\frac{3+10 K}{1+10 K}}$ & $\frac{\sqrt{3}+\sqrt{10 K}}{\sqrt{1+10 K}}$ \\
\hline 0 & 1.732 & 1.732 & 1.732 & 1.732 & 1.732 \\
\hline 0.25 & 1.209 & 1.284 & 0.909 & 1.254 & 1.771 \\
\hline 0.50 & 1.122 & 1.226 & 0.874 & 1.155 & 1.620 \\
\hline 0.75 & 1.086 & 1.196 & 0.867 & 1.111 & 1.533 \\
\hline 1.00 & 1.067 & 1.176 & 0.866 & 1.087 & 1.476 \\
\hline 1.25 & 1.054 & 1.161 & 0.868 & 1.072 & 1.434 \\
\hline 1.50 & 1.046 & 1.150 & 0.871 & 1.061 & 1.401 \\
\hline 1.75 & 1.040 & 1.141 & 0.874 & 1.053 & 1.375 \\
\hline 2.00 & 1.035 & 1.134 & 0.876 & 1.047 & 1.354 \\
\hline$\rightarrow \infty$ & 1.000 & 1.000 & 1.000 & 1.000 & 1.000 \\
\hline
\end{tabular}

From Tables 1-3, values of Eq. (15) do not decrease monotonically from $\sqrt{3}$ to 1 . Hence, Eq. (15) is no longer a possible form of $f(K)$ and is discarded. Values of Eq. (17) go above $\sqrt{3}$ and therefore Eq. (17) is also discarded. Of the remaining functions [Eqs. (13), (14), and (16)], Eq. (16) is most conservative (i.e., shows least reduction) for values of $K$ between 0 and 1, for all values of $m$ less than or equal to 1 . Values of $m$ above 1 are not to be considered because, in the absence of substantial experimental data, some conservatism is needed. Hence, Eq. (16) will be used with a value of 1 for $m$. The values of $m$ less than 1 yield very little reduction with increasing $K$ and hence are considered overly conservative. The best reduction function must be determined by examining a large number of shear-tension or shear-compression fatigue curves for a variety of materials, which has not been done for this paper due to limited time and resources. Choosing Eq. (16) with a value of 1 for $m$, Eqs. (8)-(11) become:

$$
\sigma_{e q 1, p 1}=\frac{\tau}{2} \sqrt{\frac{3+K}{1+K}}\left[-K-\sqrt{K^{2}+4}\right]
$$

for positive shear load, $x$-axis selected, 


$$
\sigma_{e q 1, p 2}=\frac{\tau}{2} \sqrt{\frac{3+K}{1+K}}\left[-K+\sqrt{K^{2}+4}\right]
$$

for negative shear load, $x$-axis selected,

$$
\sigma_{e q 2, p 1}=\frac{\tau}{2} \sqrt{\frac{3+K}{1+K}}\left[-K+\sqrt{K^{2}+4}\right]
$$

for positive shear load, $y$-axis selected, and

$$
\sigma_{e q 2, p 2}=\frac{\tau}{2} \sqrt{\frac{3+K}{1+K}}\left[-K-\sqrt{K^{2}+4}\right]
$$

for negative shear load, $y$-axis selected

These are the proposed equivalent uniaxial stresses for the biaxial shearcompression stress state in a fuse pin's fuse groove.

3. Determining the $K$ Value Through Finite-Element Modeling. To determine the equivalent uniaxial stresses using Eqs. (18)-(21), a value of $K$ is required. The best way to determine the $K$ value is to run a relatively simple contact finite-element (FE) model of the fuse pin of interest. One such fuse pin (courtesy of Goodrich Aerospace Canada Ltd.) is used for the purposes of this paper. The model was assembled, meshed and solved using ABAQUS ${ }^{\circledR}$ Standard. A suitably high fatigue load was used to run the model. Clevis symmetry was used to simplify the model. Figure 6 shows the meshed model. The fuse pin and the fuse groove can clearly be seen between the lugs.

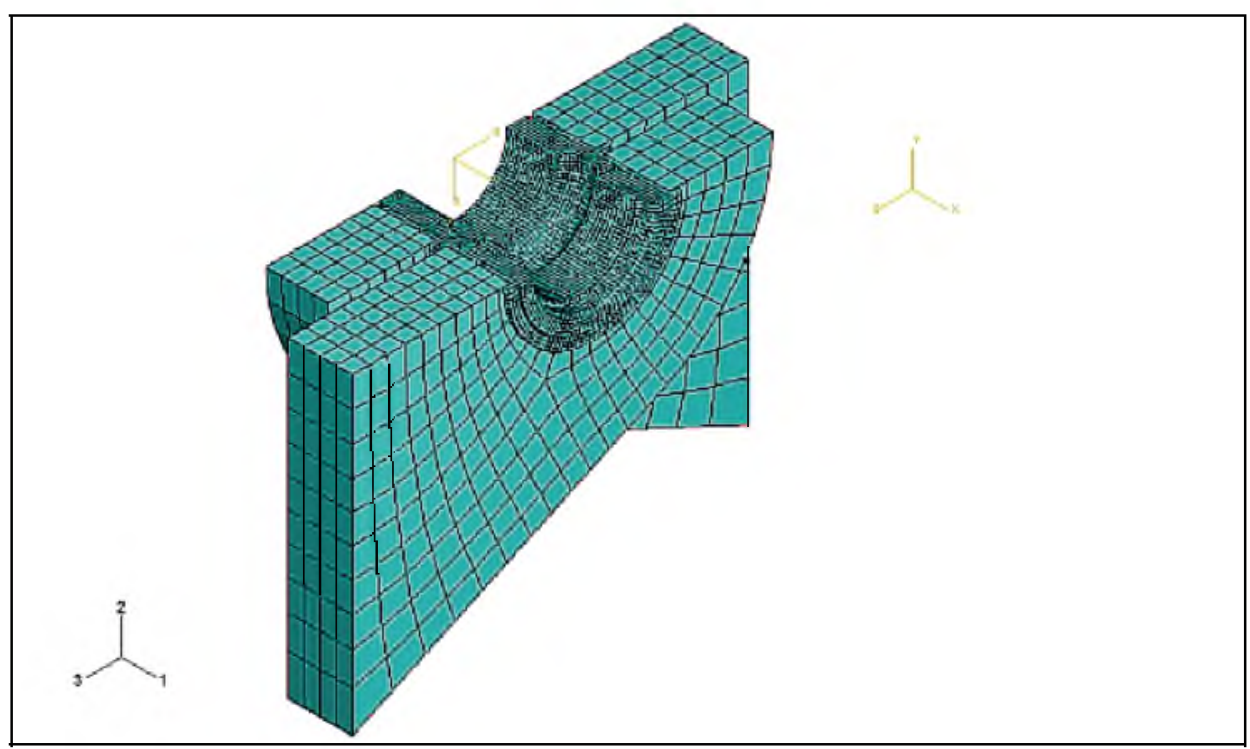

Fig. 6. Fuse pin assembly, quarter model: hex 8 mesh. 
Fully integrated 8-noded first order hexahedra are used to mesh all parts. These elements provide best results in contact simulations. A suitably fine mesh is used in the fuse groove area to compensate for the lack of higher order elements. Load is applied as a pressure on the centre lug (right lug in Fig. 6) while keeping the clevis (other) lug restrained. Suitable symmetry boundary conditions ensure that the entire assembly behaves appropriately. The von Mises results for a sample fatigue load are given in Figs. 7 and 8.

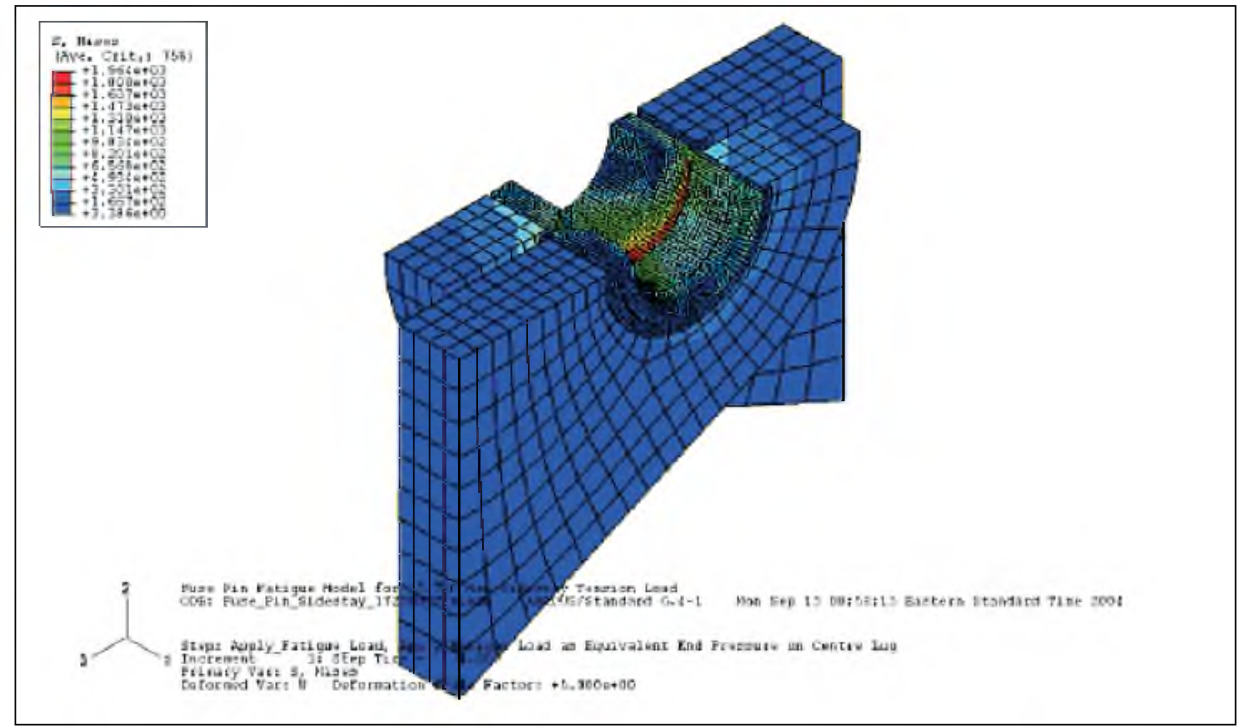

Fig. 7. Assembly von Mises stress contour plot, isoview (sample fatigue load).

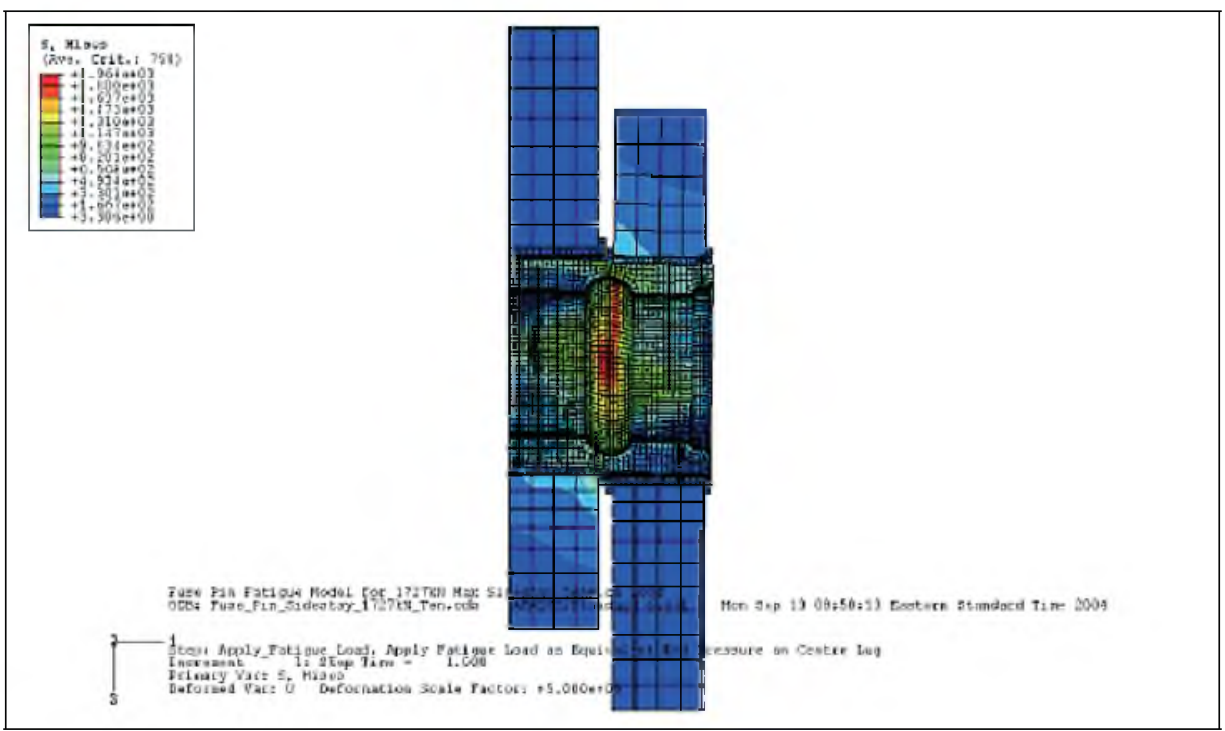

Fig. 8. Assembly von Mises stress contour plot, top view (sample fatigue load).

As expected, the maximum von Mises stress is in the fuse groove. The maximum shear stress and corresponding compressive stress in the fuse groove can easily be determined from the model. Equation (3) can then be used to 
calculate the value of $K$, which in turn is used in Eqs. (18)-(21) to calculate the proposed equivalent uniaxial stresses. In the elastic regime, the value of $K$ can be taken as approximately constant (any non-linear variation in contact stresses is neglected). For this sample fuse pin, the $K$ value is calculated as 0.5812 .

4. Results of Fatigue Analysis of Sample Fuse Pin. The value of $K$ determined using the FE model is used in Eqs. (18)-(20) to obtain the proposed equivalent uniaxial stresses. These stresses are then fed as input into any conventional discrete-section strain life fatigue analysis software that implements Neuber's correction for plasticity and a suitable mean stress correction. For this paper, Goodrich's proprietary strain life fatigue analysis software, Fatigue Life V2, was used (with permission from Goodrich Aerospace Canada Ltd.) along with a sample loading spectrum. When the proposed equivalent uniaxial stresses are used with the software, a fatigue damage of 1.60 is obtained. The analysis is repeated using a von Mises equivalent uniaxial stress based on pure shear. This excludes the relieving effect of the compressive stress. The resulting damage is 4.02.

For reliable comparison, the nodal stresses from the FE results are directly used in $\mathrm{nCode}^{\mathbb{Q}}$ FE-Fatigue ${ }^{\mathrm{TM}}$ with the same sample loading spectrum and same material properties. For accurate biaxial analysis, the Hoffman-Seeger biaxiality correction is used in FE-Fatigue. A damage of 0.69 is obtained using FE-Fatigue.

5. Discussion. The proposed equivalent uniaxial stress effectively captures the relieving effect of the compressive stress on the fatigue damage of the sample fuse pin. This is evident from the drop in fatigue damage from 4.02 for the pure shear case to 1.60 for the proposed equivalent uniaxial stress case. This is almost a three-fold reduction in fatigue damage, which is invaluable because it allows manufacturers to relax their life limitation on fuse pins.

FE-Fatigue biaxial analysis predicts a damage of 0.69 , which is half the damage obtained using the proposed model. Being industry-standard software, FE-Fatigue thus lends validity to the proposed equivalent uniaxial stress model. The proposed model is twice as conservative as should be, which is recommended in the absence of more sample runs. This conservatism is somewhat expected because of the conservative manipulations carried out on the stress state.

A more accurate reduction function can be determined using results from several experimental shear-tension or shear-compression fatigue curves, for a variety of fuse pin configurations and materials. Until that is done, it is recommended that the reduction function given by equation (16) with an m value of 1 is continued to be used. It is also recommended that the proposed equivalent uniaxial stress model be used only for preliminary design of fuse pins and not for final design and support, until experience has shown that the model predicts the fatigue damage of fuse pins accurately in a consistent and reliable manner.

Conclusions. An effective equivalent uniaxial stress model for calculating the damage of landing gear fuse pins is proposed in this paper. The proposed model takes into account the compressive stress due to bending and bearing in the location of maximum shear stress, and effectively relieves the fatigue damage on the fuse pin. A three-fold reduction in fatigue damage on the sample study fuse pin is observed using the proposed model compared to the conventional pure shear von Mises equivalent uniaxial stress model. The predicted fatigue damage is twice as high as the (valid and reliable) biaxial fatigue damage predicted by 
nCode $^{\circledR}$ FE-Fatigue ${ }^{\mathrm{TM}}$ using the nodal stresses directly from the FE model. This lends good support to the proposed model. The proposed model also happens to be conservative, which is appropriate in the absence of extensive runs. It is recommended that the proposed model be used only for preliminary design of fuse pins, and not for final design or support.

\section{Резюме}

Розглянуто умови двовісного напруженого стану запобіжних елементів шасі шплінтів у запобіжних вузлах. У цьому випадку має місце поєднання дотичних напружень, рівень яких відповідає максимально допустимому рівню напружень у конструкції, та стискальних напружень, щц визначаються з умов рівноваги. Згідно зі стандартними методиками розрахунку на утому таке поєднання напружень заміняється еквівалентним одновісним напруженням на основі умов чистого зсуву по Мізесу. При цьому розрахункові характеристики матеріалу від утомленості $\epsilon$ значно вищими за експериментальні, що отримані при випробуваннях шплінтів на утому. Запропоновано модель еквівалентного одновісного утомного напруження, в якій враховується розвантажувальний ефект стискальних напружень. Модель використовується в рамках стандартного пакета програм розрахунку деформаційних кривих утоми (Goodrich Aerospace's Fatigue Life V2) для оцінки утомної довговічності запобіжного шплінта пасі під дією циклічного навантаження. Отримані результати порівнюються з визначеними за допомогою моделі чистого зсуву і розрахункової скінченноелементної програми. Використання запропонованої моделі гарантує оцінку утомної довговічності менш консервативну, аніж за еквівалентною моделлю Мізеса, але більш завищену порівняно з двовимірним скінченноелементним розрахунком.

1. C. A. Gonçalves, J. A. Araújo, and E. N. Mamiya, "Multiaxial fatigue: a stress based criterion for hard metals," Int. J. Fatigue, 27, 177-187 (2005).

2. I. T. Kim and K. Yamada, "Fatigue life evaluation of welded joints under combined normal and shear stress cycles," Ibid, 1-7 (2005).

3. H. Kyuba and P. Dong, "Equilibrium-equivalent structural stress approach to fatigue analysis of a rectangular hollow section joint," Ibid, 85-94 (2005).

4. N. Hong and L. Shaobo, "Biaxial stress fatigue life prediction by the local strain method," Ibid, 19, 517-522 (1997).

5. A. Carpinteri and A. Spagnoli, "Multiaxial high-cycle fatigue criterion for hard metals," Ibid, 23, 135-145 (2001).

6. M. Bäckström and G. Marquis, "A review of multiaxial fatigue of weldments: experimental results, design code, and critical plane approaches," Fatigue Fract. Eng. Mater. Struct., 24, 279-291 (2001).

7. MIL-HDBK-5H. Metallic Materials and Elements for Aerospace Vehicle Structures (1998).

8. ABAQUS ${ }^{\circledR}$ Standard V6.4 Analysis User's Manual.

9. $n$ Code ${ }^{\mathbb{Q}}$ FE-Fatigue ${ }^{\mathrm{TM}}$ User's Manual. 